
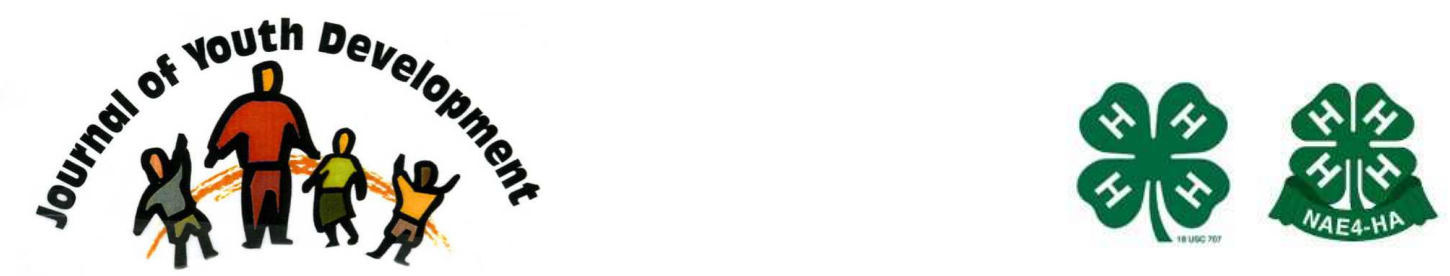

Bridging Research \& Practice

\title{
Projects in a Day Develop Life Skills in At-Risk After School Youth
}

\author{
Katie J. Hoffman \\ University of Idaho Extension \\ Salmon, ID \\ khoffman@uidaho.edu
}




\title{
JOURNAL OF YOUTH DEVELOPMENT \\ bridging research and practice

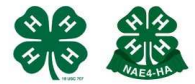

Volume 6, Number 2, Summer 2011

Article 110602PA003

\section{Projects in a Day Develop Life Skills in At-Risk After School Youth}

\author{
Katie J. Hoffman \\ University of Idaho Extension
}

\begin{abstract}
As budgets tighten and school weeks are shortened more youth are being left unattended at home. Rural youth are particularly affected by these reductions and stranded away from programs and resources. At-risk youth are acutely impacted as they lose contact time with programs that provide life skill development and a safe place for youth to connect to community, other youth and adults. 4-H Projects-ina-Day can provide curriculum in partnership with after school programs that develop life skills and build positive social skills. In a study conducted with an Idaho After School program during the 2007-2008 and the 2008-2009 school years, six of the 12 life skills evaluated showed a significant increase after participation. Youth also reported positive self esteem and made new friends during the events held on Fridays. 4-H Project-in-a-Day curriculum has shown to be a powerful, ready to use tool in after school programming.
\end{abstract}

\section{Introduction}

School districts across the country are meeting economic challenges by reducing the school week to four days. Over 120 school districts have implemented shortened school weeks (Turner, 2010), lengthening the school day to make up for the reduced instruction days.

However, this strategy may be resulting in another problem, youth left unattended on out of school days. This is a particular problem in the rural United States as many rural parents are not home and youth are stranded away from other resources and programs (Letiecq, Bailey \& Keller, 2007). Youth left unsupervised for a long day are at risk of negative behavior choices with adverse consequences to themselves and their community. Youth are engaged in more positive behavior when they are connected to parents, family, school, community, and places of worship (White House, 2005). 
4-H curricula are particularly well suited to many out-of-school youth programs. 4-H curriculum not only reduces risky behavior but builds life skills. 4-H has expanded to include the popular Project in a Day format, in which youth complete all project requirements in one day. In 2006 the National 4-H Headquarters reported that 168,808 youth in the Western United States participated in short term 4-H projects such as Projects in a Day -- eleven times greater than traditional Overnight Camp enrollment at 15,203 youth and 25,535 youth who were enrolled in Day camping projects (National 4-H Headquarters, 2006). Projects-in-a-Day have great potential for after school programs, and may be the only option for some youth to participate in 4-H (Lemhi County 4-H, 2007). They are particularly well suited to the full-day youth program challenges faced by the many communities with shortened school weeks.

In 2007 the Salmon, Idaho School District adopted a four day school week. Youth attend school Monday through Thursday, greatly impacting youth attending the Lemhi's After School Promise Program (LASP). These youth are already considered at-risk, having been referred to the program by teachers, counselors, law enforcement personnel, administrators and/or domestic violence and family service personnel. The school schedule change reduced LASP program contact time with youth from 10 hours to six hours each week. LASP youth are not released from school until 4:00pm, an hour later than under the past school programming. Contact time is reduced by one hour each day greatly reducing the youth's opportunities to participate in a program offering life skill development and prevention curriculum. Positive adult interaction and enrichment activities outside of homework are limited as well.

Lemhi's After School Promise functions as a 501(c)3 non-profit and operates independently of the school district. The program operates on grant funding from several organizations promoting drug and alcohol preventions curriculum, academic improvement and life skill development. Three instructors, including two certified teachers, provide programming and healthy adult interactions during contact time.

\section{Fabulous 4-H Friday Program}

A partnership with Lemhi's After School Promise, Lemhi County 4-H and University of Idaho Extension was formed to meet the needs of the at-risk youth and reduce risky behavior on Fridays. 4-H after school programs build positive social skills, offers positive alternatives to anti social behavior and support parents in care giving (Bunnell \& Pate, 2006). Furthermore, the program provides life skill development and a safe place for youth to connect to community, other youth and adults. Since the youth attending on Fridays varied each week, a traditional project was not feasible and often did not hold the youth's interest. The Partnership selected 4-H curriculum to utilize in the Friday "Project in a Day" Program. 4-H curriculum is already developed, tested for effectiveness and inexpensive to obtain. The incorporation of a 4-H Project in a Day met the LASP prevention and enrichment goals and encouraged youth participation.

During the 2007-2008 and 2008-2009 school years, 4-H and the LASP offered a series of Projects-in-a-Day held every other Friday during both Fall and Spring LASP programming. Seven events were held in the 2007-2008 school year and six events during the 2008-2009 school year. The program was called "Fabulous 4-H Fridays" and was possible with assistance from several grants totaling $\$ 1500$. Events included five hours of contact time with youth, a lunch provided by LASP and a 4-H project. Lunch was provided at no cost to youth that qualified for the free and reduced lunch program. The 4-H Project in a Day consisted of a basic introduction to the project, a modified record book, a short demonstration and a service learning project. A 
$\$ 10.00$ fee was requested for each event but all youth received scholarships through LASP, or Lemhi County 4-H. Over 28 individual youth attended the program with and average of 12 participants at each event.

\section{Why Projects in A Day Work}

The Project-in-a-Day format offered youth exposure to 4-H's fundamental goal of life skill development while developing project specific skills. 4-H curriculum is based on 34 life skills and developed by professionals in youth development (Hendricks, 1996). The Life Skill Model emphasizes learning by doing. Programming and curriculum is designed to "provide opportunities for youth to experience life skills, to practice them and be able to use them throughout their lifetime" (Iowa State 4-H, 2007, p.1)

The shortened format allowed youth to experience the 4-H project in a few hours, learn basic skills and determine if the project was something of interest to them. Youth were able to try projects they may never have signed up for, including theatre or Making the Most of Me. Within a day, youth complete a project, finish a record book and give a demonstration, all essential elements of the 4-H experience (4-H Delivery Modes, 2002). Each Friday session began with a brief overview of the topic to be covered for the day. Youth were then able to build goals for the day and record then in their record books. Following a formal discussion on the topic youth participated in hands on learning activities including acting exercise, seed starting and rocket building. Youth took lessons learned from hands on learning experiences and prepared a presentation for the group. During the presentation public speaking skills are built as youth share what they learned with others. Completion of record books follow the demonstration portion of the "Project in a Day" programming. In addition, youth complete a service learning project. Based on the National 4-H Experiential Learning Model, 4-H curriculum is designed to let youth experience, reflect on that experience and apply that knowledge to other life situations (Diem, 2001). Even though Projects in a Day are shortened versions of traditional 4-H projects they still retain the necessary pieces to follow the experiential learning model and develop life skills.

\section{Methods}

Evaluation of the Fabulous 4-H Fridays "Project in a Day" program consisted of a pre- and posttest survey and a personal interview. The pre-test surveys provided a basal level of life skills before the event to compare to life skills after the event. The pre- and post-test surveys were researcher designed survey instruments with 12 quantitative questions, each addressing a specific life skill - see Table 1 for the 12 skills and questions included. The surveys used a rating system from one to five, with one being "Very Poorly," two being "Not so Well," three being "OK," four being "Very Well" and five being "Excellent."

The interview portion of the research was conducted after the service learning project during the 2007-2008 school year. Two youth were randomly selected from each session through an identification number system, for a total of 15 youth interviewed. The interview was conducted by the researcher. Each interviewed youth was asked 12 quantitative researcher designed questions. The questions are similar to the ones on the pre-test and post-test surveys. The questions focused on specific events during the activity, for example "Did you finish your record book today?" Some of the questions were open ended, for example "How did you feel about yourself today?" Youth were read the questions and the researcher wrote the youth's answers verbatim. 


\section{Impacts}

Evaluation results for the program showed that at-risk youth participating in the Fabulous 4-H Friday program received life skill education and learned project specific skills while participating in the program. In a pre-then-post survey conducted during the 2007-2008 and 2008-2009 school year 11 of the 12 life skills evaluated increased.

The following six life skills showed a statistically significant increase through participation:

- Wise Use of Resources

- Record Keeping

- Problem Solving

- Decision Making

- Contributions to Group Effort

- Marketable Skills

Five life skills showed a slight but not a significant increase:

- Goal Setting

- Learning to Learn

- Leadership

- Teamwork

- Self Motivation

The Community Service life skill showed a decrease in confidence levels. Confidence levels of an average of 4.5 were recorded in pre test. The post test average dropped to 4.28. This was not a statistically significant difference and may be contributed to self reporting error. The interview data collected also reflected that a reporting error may have occurred. Each youth interviewed was able to state a specific way they helped others during the day and ways they could help in the future.

During interviews with participants, 80 percent reported a positive response when asked if they completed the record books, learned a specific skill or helped others. Eighty percent shared a specific skill they had learned and a way they had helped someone else. Ninety-three percent of participant interviewed reported positive responses to a question assessing their ability to reach their goals for the event and also stated they had positive feelings about themselves while attending the Fabulous 4-H Friday events. Seventy-three percent shared a positive response when asked if they used their resources wisely while 67 percent said they contributed to group effort and were helped by others. Forty percent of youth reported a positive response when asked if they were a leader. 
Table 1

Comparison of Means and $t$-tests $N=72$

\begin{tabular}{|c|c|c|c|c|c|}
\hline \multicolumn{6}{|c|}{ Table 1. Comparison of Means and t-tests } \\
\hline Life Skills & Confidence & Survey Questions & $M$ & $S D$ & $T$ \\
\hline \multirow[t]{2}{*}{$\begin{array}{l}\text { Wise use of } \\
\text { Resources }\end{array}$} & Pre-test & $\begin{array}{l}\text { How well do you manage your time so that } \\
\text { you can get things done? }\end{array}$ & 4.07 & 1.28 & $4.30^{*}$ \\
\hline & Post- test & $\begin{array}{l}\text { How well did you manage your time so that } \\
\text { you could finish your project? }\end{array}$ & 4.81 & 0.69 & \\
\hline \multirow[t]{2}{*}{ Goal Setting } & Pre-test & How hard do you work on things you do? & 4.38 & 1.12 & 1.50 \\
\hline & Post- test & How well did you do on your project? & 4.64 & 0.98 & \\
\hline \multirow[t]{2}{*}{ Record Keeping } & Pre-test & How well do you keep records? & 3.12 & 1.73 & $4.60^{*}$ \\
\hline & Post- test & How well did you do on your record book? & 4.29 & 1.28 & \\
\hline \multirow[t]{2}{*}{ Learning to Learn } & Pre-test & Do you learn new things? & 4.51 & 1.15 & -1.55 \\
\hline & Post- test & Did you learn new things? & 4.76 & 0.74 & \\
\hline \multirow[t]{2}{*}{ Problem Solving } & Pre-test & How well do you work through problems? & 4.18 & 1.27 & $2.29^{*}$ \\
\hline & Post- test & $\begin{array}{l}\text { How well did you work through problems you } \\
\text { had today? }\end{array}$ & 4.60 & 0.88 & \\
\hline \multirow[t]{2}{*}{ Decision Making } & Pre-test & How well do you make decisions? & 4.14 & 1.30 & $2.81^{*}$ \\
\hline & Post- test & $\begin{array}{l}\text { How well did you make decisions about your } \\
\text { project today? }\end{array}$ & 4.67 & 0.92 & \\
\hline \multirow[t]{2}{*}{ Community Service } & Pre-test & How well do you help other people? & 4.50 & 1.06 & -1.11 \\
\hline & Post- test & $\begin{array}{l}\text { How well did you help someone today during } \\
\text { the project? }\end{array}$ & 4.28 & 1.32 & \\
\hline \multirow[t]{2}{*}{$\begin{array}{l}\text { Contributions to } \\
\text { Group Effort }\end{array}$} & Pre-test & $\begin{array}{l}\text { How well do you share your talents with } \\
\text { others? }\end{array}$ & 4.01 & 1.32 & $2.27^{*}$ \\
\hline & Post- test & $\begin{array}{l}\text { How well did you share your supplies or give } \\
\text { advice to others today? }\end{array}$ & 4.47 & 1.10 & \\
\hline \multirow[t]{2}{*}{ Leadership } & Pre-test & How well do you lead groups? & 4.11 & 1.38 & -1.45 \\
\hline & Post- test & How well did you help lead the group? & 4.43 & 1.25 & \\
\hline \multirow[t]{2}{*}{ Teamwork } & Pre-test & $\begin{array}{l}\text { How well do you work with groups to finish } \\
\text { activities? }\end{array}$ & 4.53 & 1.15 & 1.19 \\
\hline & Post- test & $\begin{array}{l}\text { How well did your group work together to } \\
\text { finish the project? }\end{array}$ & 4.72 & 0.77 & \\
\hline \multirow[t]{2}{*}{ Marketable Skills } & Pre-test & $\begin{array}{l}\text { How well do you keep working on things until } \\
\text { they are finished? }\end{array}$ & 4.28 & 1.13 & $2.47^{*}$ \\
\hline & Post- test & $\begin{array}{l}\text { How well did you keep working on your } \\
\text { project until it was finished? }\end{array}$ & 4.69 & 0.88 & \\
\hline \multirow[t]{2}{*}{ Self Motivation } & Pre-test & How well do you learn new skills? & 4.40 & 1.12 & -1.90 \\
\hline & Post- test & $\begin{array}{l}\text { How well did you do learning new skills } \\
\text { today? }\end{array}$ & 4.71 & 0.78 & \\
\hline
\end{tabular}

Nine interviewed youth reported they had made a new friend during the event and 5 youth shared that although they became angry during an event they were able to handle the situation. Each interviewed participant was able to state at least one specific community service they could perform to help someone else. Although the pre and post - test survey data did not reflect a statistically significant increase in the confidence level, the interview responses showed that there was an increase in awareness of the community service life skills. 
The Fabulous 4-H Friday program provides 4-H Project in a Day programming that develops life skills in youth at risk as well as increasing youth's self esteem. We have been able to continue the program in 2009-10, and the program will continue in the Fall of the 2010-2011 school year.

Evaluation of the findings show 4- $\mathrm{H}$ curriculum as a viable partner in after school programming. Projects in a Day can provide an after school environment with important life skill development and healthy adult interaction. The short format fits nicely into afterschool programming where little prep time or contact time is available. The "learning by doing" structure" allows for hands on learning and reinforcement of skill development.

\section{Recommendations}

This ready to use curriculum is well suited to implement in school districts with shortened school weeks and provide youth with positive self growth. Almost any current 4-H project can be used in a Project in a Day format giving both, youth and instructors, flexibility to meet skill needs and interest. Including hands on learning experiences in which youth are actively engaged in learning, doing and reflecting will build life skills during almost any Project in a Day. Youth professionals are able to tailor Project in a Day programming to meet youth's interest while developing life skills in a shortened format.

\section{References}

4-H Delivery Modes. (2002). Retrieved January 5, 2008, from University of Maryland, Division of Agriculture Cooperative Extension Service Web site:

http://extension.umd.edu/4H/4HEnrollDef.pdf

Bunnell, J., \& Pate, R. (2006). 4-H Afterschool - Making an Impact. Journal of Youth

Development, Volume 1 Number 1, Retrieved July 15, 2010 from

http://web.memberclicks.com/mc/page.do?sitePageId=101250\&orgId=nae4a

Diem, K.G. (2001). Learning by Doing the 4-H Way. Retrieved July $15^{\text {th }}, 2010$, from Rutgers Cooperative Extension, New Jersey 4-H Web site:

http://njaes.rutgers.edu/pubs/pdfs/4H/e148/447-454/pdf

Hendricks, P.A. (1996). Targeting life skills model. Retrieved September 16, 2006, from University of Arkansas, Division of Agriculture Cooperative Extension Service Web site: http://www.uaex.edu/Other Areas/publications/PDF/4HCC5.pdf

Iowa State 4-H. (2007). Retrieved January 5, 2008, from University of Iowa, Division Extension Education Web site: http://www.iastate.edu

Lemhi County 4-H. (2007).What is Lemhi County 4-H? [Brochure]. Salmon, ID: Katie Hoffman.

Letiecq, B., Bailey, S., \& Keller, J. (2007). Rural after-school programs: Meeting the Needs of At-Risk Youth and Their Families. Journal of Youth Development, Volume 2, Number 2, Retrieved July 15, 2010 from: http://web.memberclicks.com/mc/page.do?sitePageId=101250\&orgId=nae4a 
National 4-H Headquarters. Retrieved January 5, 2007, from the National 4-H Headquarters web site: http://www.national4-hheadquarters.gov/emblem/4h name.htm

Turner, D. (2010, June 4). 4-day school weeks gain popularity across US. Retrieved July 15, 2010, from http://news.yahoo.com/s/ap/20100604/ap_on_re_us/us_four_day_school_week/ print;_ylt=Akilbt_16zZ5Jpic18E.k95H2ocA;_ylu=X3oDMTBvajKkaTFyBHBvcwMxNQrzZWMDdG9w BHNsawNwcmludA-

White House Fact Sheet. (2005). A commitment to helping America's youth. Retrieved January 5, 2008, from http://www.whitehouse.gov/news/releases/2005/10/20051027.html

(C) Copyright of Journal of Youth Development Bridging Research and Practice. Content may not be copied or emailed to multiple sites or posted to a listserv without copyright holder's express written permission. However, users may print, download or email articles for individual use. 